
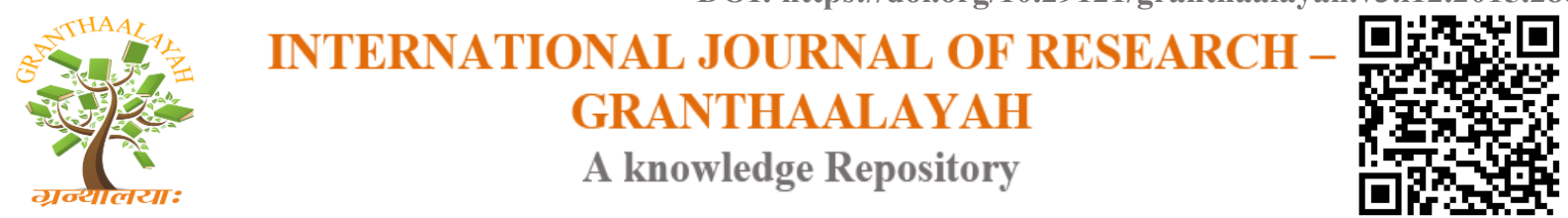

Social

\title{
ROLE OF KUDUMBASHREE AND WOMEN EMPOWERMENT: A STUDY OF THIRUVANANTHAPURAM MUNICIPAL CORPORATION AREAS IN KERALA STATE, INDIA
}

\author{
Jomy Jose ${ }^{* 1}$ \\ ${ }^{* 1}$ MLISc, NET, Asst. Librarian, Asian School of Business, Technocity, Thiruvananthapuram, \\ Kerala, INDIA
}

\begin{abstract}
The empowerment of women through different laws, legislations, activities and schemes is the most important concern of 21st century. This study explores the role of Kudumbashree and its impact on women empowerment in Kerala with special reference to Thiruvananthapuram Municipal Corporation area. Kudumbshree is a practical model for strengthening the Self Help Group (SHG) based poverty alleviation programme. Questionnaire and interview were used for collecting the data. The study found that, Kudumbashree leads to sustainable social, economic development of women and a direct impact on their living status, educational, nutritional and health needs of their children, positively.
\end{abstract}

Keywords:

Kudumbashree, Women Empowerment, Poverty alleviation, Self Help Group Kerala.

Cite This Article: Jomy Jose, "ROLE OF KUDUMBASHREE AND WOMEN EMPOWERMENT: A STUDY OF THIRUVANANTHAPURAM MUNICIPAL CORPORATION AREAS IN KERALA STATE, INDIA" International Journal of Research - Granthaalayah, Vol. 3, No. 12(2015): 72-82. DOI: 10.29121/granthaalayah.v3.112.2015.2888.

\section{INTRODUCTION}

Kudumbashree was launched by the Government of Kerala in 1998 with an aim to eradicate poverty in rural and urban areas of Kerala through community development schemes, under the leadership of Local Self Governments. It is now considered as one of the largest womenempowering projects in India. The programme is linked to local self-government institution and it makes all the effort to alleviate poverty through an integrated approach involving effective union of resources and action. It combines different kind of activities like thrift and credit, micro enterprises, income generating activities and a wide range of welfare activities. Kudumbashree chooses a family based approach; it reaches the family through women and the community through these families. Kudumbashree forms self-help groups with members preferably from the same socio-economic background and a village-based financial intermediary usually composed of 10-20 local women. Each member makes a small regular savings contribution over a few 
months for generating a capital within the group. After that SHG can begin lending services to its members without any collateral security. The collected funds may then be lent back to the members to serve different purposes. Many SHG's are associated with banks for the delivery of micro-credit. The Reserve Bank of India has issued instructions permitting the nearest Commercial or Regional Rural Bank, or even a Cooperative Bank to open Savings Bank account for SHGs. Kudumbashree is thus granted the same privileges. It thus chooses to focus on three major aspects ie; Women empowerment, economic empowerment and social empowerment through the use of such allocated funds.

Kerala, the south-west region of India on the Malabar Coast is bordered by Karnataka to north and north-east, Tamil Nadu to the east and south, and Arabian Sea to the west. The state capital is Thiruvananthapuram. The Thiruvananthapuram Municipal Corporation administrates the city of Thiruvananthapuram, and is the largest city corporation in Kerala by area and population. The corporation is spread over $214.86 \mathrm{~km}^{2}$. Like with the corporation system of Kerala, Thiruvananthapuram Municipal Corporation too is further regionalized into wards. It functions with 100 wards and forms a strong ground for a study of Kudumbshree.

\section{STRUCTURE OF KUDUMBASHREE}

Kudumbashree has three tiers community based organization (CBO) for its effective administration and decentralized operations. Neighborhood group (NHG ) - This is the lowest tier consisting of 15 to 40 women members from poor families. Meetings are arranged on a weekly basis, in the house of one of the NHG members. The Area Development Society (ADS) is the second tier. ADS are formed at ward level- panchayat, municipality or a corporation by joining 10-15 NHGs. The Community Development Society (CDS) is the highest tier formed by union of all the ADSs in the respective panchayat, in 'rural' or municipality and in 'town' or corporation in city areas. It monitors the thrift and credit activities of NHGs at these levels ie. panchayat or municipality or corporation level.

\section{WOMEN'S EMPOWERMENT}

In many discussions and studies it is found that women have been treated as second class citizens of all across the globe. It is a fact that almost common everywhere, irrespective of the development index of a country, women have always been subjected to denied rights and support systems for their adequate functional growth. This situation is caused due to loss of women's self-dignity as human beings over time under such conditions. Women are not independent entities. Especially in Kerala, they are found to be fully associated and dependent on men particularly in addition to other aspects in the context of intellectual and professional capabilities. One of the remedies then, is to improve the women status in society which has consequently become the goal of various Women empowerment schemes. Empowerment has been considered an effective tool to bring about changes in the socio-economic conditions of women. A nation, society as well as the individual himself or herself, cannot progress adequately until the status of women in the region is improved, in the very least. Gandhi (1930) written about the role of women in society that "to call woman the weaker sex is a libel; it is man's injustice to woman. If by strength is meant brute strength, then, indeed, is woman less brute than man. If by strength is meant moral power, then woman is immeasurably man's superior. Has she not greater intuition, 
is she not more self-sacrificing, has she not greater powers of endurance, has she not greater courage? Without her, man could not be. If nonviolence is the law of our being, the future is with woman. Who can make a more effective appeal to the heart than woman?"

According to United Nations, Women's empowerment definition has five major components:

- women's sense of self-worth;

- their right to have and to determine choices;

- their right to have access to opportunities and resources;

- their right to have the power to control their own lives, both within and outside the home;

- Their ability to influence the direction of social change to create a more just, social and economic order, both nationally and internationally.

\section{LITERATURE REVIEW}

Manjusha (2010) assessed the level of empowerment achieved by the womenfolk of Ulladan Tribe of the North Paravur Taluk in Ernakulam District of Kerala. The study is an attempt through Kudumbshree units. The findings show that a significant change has come about in the socio-economic life of the women folk in the Taluk. Change was also observed in the political avenues as well as the general skills of the respondents through the Kudumbshree Units. The study suggested that for future development, training and awareness programmes should be conducted for empowering the poor women in that area.

Kenneth and Seena (2012) studied the impact of various programmes that were introduced in order to raise the women from below poverty line in Puthanvelikkara Grama Panchayat of Ernakulum, Kerala. The Questionnaire method was adopted in this study for collecting primary data. The results of the study show that economic development is the base for other developments and Kudumbshree units drastically changed economic independence of the women and their living status.

Beevi and Devi(2011) conducted a study with an aim to assess the role of Self Help Groups in empowering rural women and to identify the major constraints faced by women in Kollam District of Kerala. The study revealed that micro-enterprises are a practicable pathway for improving the economic status. Some factors like education, income and mass media contact were positively and significantly related to the role of the SHGs. The effectiveness of the SHGs in promoting women empowerment was found to be limited by only factors like hesitation to take up innovative scheme; difficulty in playing dual roles by women; lack of confidence, team spirit, effective leadership, managerial skills, working capital and transportation. These thus were found to be the major constraints faced by SHGs.

Jaya (2004) evaluated the functioning of SHGs and identified the factors contributing to the successful functioning and sustainability of groups in Kerala. This was achieved through an exploratory study of selected SHGs in the district of Malappuram in Kerala. The findings of the study show that SHG intervention has indeed improved the living standards. Interestingly, it also inculcated saving and loan repayment habits and brought about a positive change in attitudes and social skills of $52 \%$ of the respondent women folk thereby leading to empowerment. 
Contrastingly, Shylendra (1998) assessed performances of eight women SHGs in Vidaj village of Gujarat. The SHGs, it was found, failed to enable members realize their potential benefits. The failure was attributed to wrong approaches followed in the SHG formation, lack of clarity about the SHG goals and concept among the members. The study brought to light the need to constitute SHGs with clear understanding of the concept from the beginning itself.

Minimol and Makesh (2012) did a study to identify the level of personal, social, economic and financial empowerment achieved by the members through SHGs. The data was collected from a sample of 200 members of 18 SHGs located within three villages of Cherthala Taluk of Alappuzha, Kerala. Primary data were collected by employing a structured interview schedule, through participant observation, and direct personal discussions with the members of various SHGs. The study concluded that the concept of SHGs for rural women empowerment has not yet run its full course in attaining its objective.

Kavitha et.al (2011) conducted a study on the general acumen of effectiveness of group functioning by the members of women self-help groups (SHGs) in goat farming, operating under Kudumbashree, in Thrissur district, Kerala. The findings of the study showed that majority of the respondents $(76 \%)$ perceived the effectiveness of their group functioning as medium. The functioning of the group in terms of official procedures (mean score 1.96) was perceived most effective by the members, followed by that of interpersonal relationships (mean score 1.93) and entrepreneurial activities (mean score 1.76). The study brought to light the need for entrepreneurial training in goat farming along with provision of resources like good quality breeds, grazing land, feed, market and veterinary care for success of the group's functioning

\section{OBJECTIVES OF THE STUDY}

The study was conducted among the Kudumbashree members of Thiruvananthapuram Corporation area in Kerala state only.

The present study was undertaken with the following objectives:

- To identify the major factors on the empowerment women

- To determine the Age, marital Status and education level of Kudumbshree members

- To measure the usefulness of Kudumbashree for women empowerment

- To know income level of women per year after joining a Kudumbashree unit

- To know the Occupation-wise Distribution of Kudumbashree Members

- To give suggestions for the empowerment of women in future policy making of Kerala State

\section{METHODOLOGY}

The population of the study is the Kudumbashree members of Thiruvananthapuram municipal corporation area. The field survey was carried out covering all areas of Thiruvananthapuram Municipal Corporation. The sample population includes those members who were active in the Kudumbshree group during the period, January 2010- December 2014. A pre-tested structured questionnaire prepared in local language was used. The Kudumbshree members were individually met for collecting accurate data directly. A random sample of 250 members was selected for the study. 


\section{DATA ANALYSIS}

The age wise distribution of women of Thiruvananthapuram Municipal Corporation area is as tabulated in table -1 .

Table 1: Age wise distribution of women

\begin{tabular}{|l|l|l|l|}
\hline Sl. No. & Age Slots & $\begin{array}{l}\text { Number } \\
\text { respondents }\end{array}$ & $\begin{array}{l}\text { of } \\
\text { Percentage of } \\
\text { respondents }\end{array}$ \\
\hline 1 & $18-23$ & 8 & 3.2 \\
\hline 2 & $24-29$ & 71 & 28.4 \\
\hline 3 & $30-35$ & 79 & 31.6 \\
\hline 4 & $36-41$ & 34 & 13.6 \\
\hline 5 & $42-47$ & 25 & 10 \\
\hline 6 & $48-53$ & 19 & 7.6 \\
\hline 7 & $54-59$ & 10 & 4 \\
\hline 8 & $\begin{array}{l}60 \\
\text { above }\end{array}$ & 4 & 1.6 \\
\hline & Total & $\mathbf{2 5 0}$ & $\mathbf{1 0 0}$ \\
\hline
\end{tabular}

The table highlights that most of the members fell within the 30-35 age slab (31.6percentage). The second the highest no of respondents fell within 24-29 age slab (28.4percentage) and the rest 13.6 percentage of the total 250 respondents came under 36-41.

Age wise distribution of women

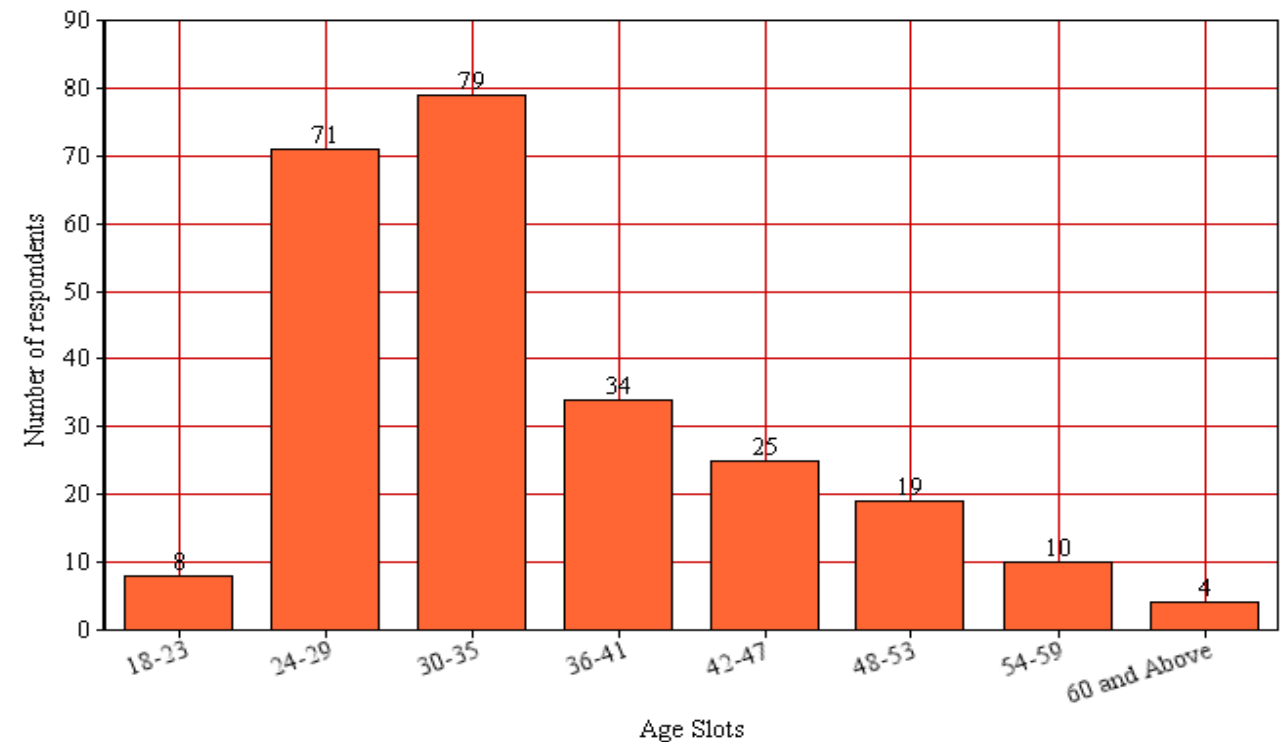

Figure 1: Age wise distribution of Kudumbshree Members 
The marital status of the Kudumbshree members was also ascertained at the time of interview and the data collected was compiled and tabulated in table below:

Table 2: Marital Status of the Kudumbshree Members

\begin{tabular}{|c|c|c|c|}
\hline $\begin{array}{l}\text { Sl. } \\
\text { No. }\end{array}$ & $\begin{array}{l}\text { Marital } \\
\text { Status }\end{array}$ & $\begin{array}{l}\text { Number } \\
\text { respondents }\end{array}$ & $\begin{array}{l}\text { Percentage } \\
\text { respondents }\end{array}$ \\
\hline 1 & Unmarried & 39 & 15.6 \\
\hline 2 & Married & 193 & 77.2 \\
\hline 3 & Widowed & 12 & 4.8 \\
\hline 4 & Divorced & 6 & 2.4 \\
\hline & Total & 250 & 100 \\
\hline
\end{tabular}

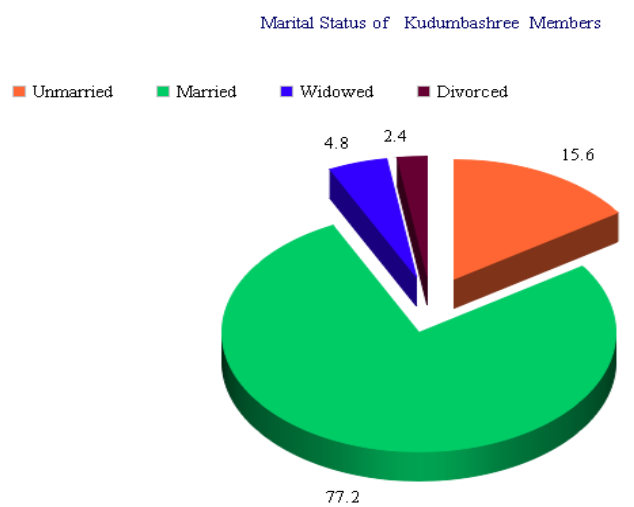

The Education level of the Kudumbshree members was compiled and tabulated as shown below:

Table 3: Education level of women

\begin{tabular}{|l|l|l|l|}
\hline Sl. No. & Education & $\begin{array}{l}\text { Number of } \\
\text { respondents }\end{array}$ & $\begin{array}{l}\text { Percentage of } \\
\text { respondents }\end{array}$ \\
\hline 1 & Below SSLC & 14 & 5.6 \\
\hline 2 & SSLC & 89 & 35.6 \\
3 & Plus Two/Pre-degree & 78 & 31.2 \\
4 & Diploma & 31 & 12.4 \\
\hline 5 & Graduation & 29 & 11.6 \\
\hline 6 & Post-Graduation & 9 & 3.59 \\
\hline & Total & $\mathbf{2 5 0}$ & $\mathbf{1 0 0}$ \\
\hline
\end{tabular}


Education level of women tabulated in Table -3 shows that $35.6 \%$ has passed the secondary school education and 31.2 has plus two/pre-degree, $12.4 \%$ has diploma education which includes polytechnic and other technical job related diploma courses. While $11.6 \%$ has graduation, $3.59 \%$ of the total 250 respondents are post graduates.

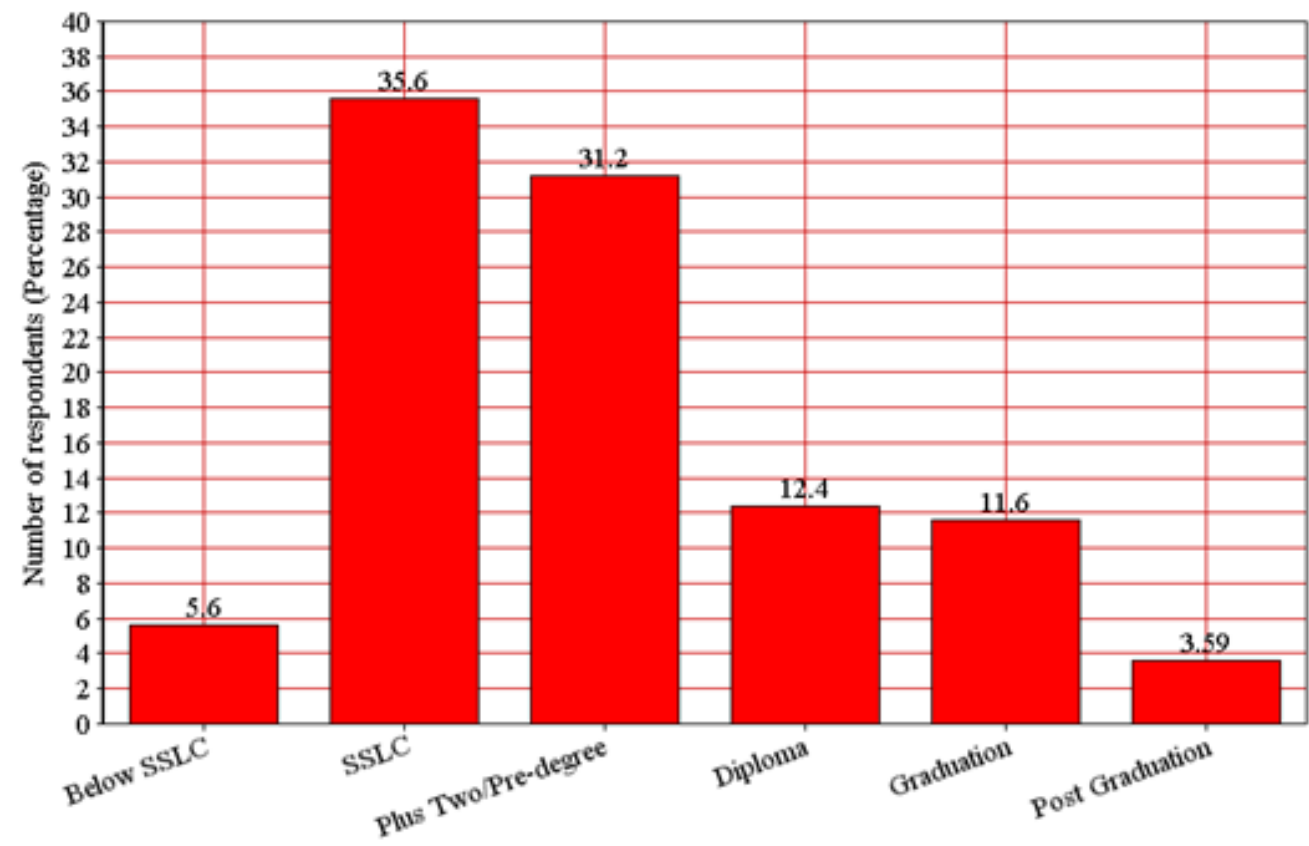

Figure 2: Education distribution of Kudumbshree Members

Table 4: Major factors for the empowerment of women as per respondents' views

\begin{tabular}{|l|l|l|l|}
\hline Sl. No. & Factors & $\begin{array}{l}\text { Number of } \\
\text { respondents }\end{array}$ & Percentage \\
\hline 1 & Training & 20 & 8 \\
\hline 2 & $\begin{array}{l}\text { Entrepreneurship } \\
\text { skill }\end{array}$ & 12 & 4.8 \\
\hline 3 & Funding & 61 & 24.4 \\
\hline 4 & Coordination & 10 & 4 \\
\hline 5 & Support form NGO & 14 & 5.6 \\
\hline 6 & Support form Govt. & 60 & 24 \\
\hline 7 & Support form Family & 73 & 29.2 \\
\hline & Total & $\mathbf{2 5 0}$ & $\mathbf{1 0 0}$ \\
\hline
\end{tabular}

Table-4 reveals the most important factors for empowerment of women according to the respondents. 73 respondents out of $250(29.2 \%)$ said that support from family is the most important factor. Besides this, funding and support from the government were considered the next most important factors $(24.4 \%$ and $24 \%$ respectively). 
Table 5: Usefulness of Kudumbshree in a respondent's life

\begin{tabular}{|c|c|c|c|}
\hline Sl.No. & Factors & $\begin{array}{l}\text { Number } \\
\text { respondents }\end{array}$ & of Percentage \\
\hline 1 & Very useful & 130 & 52 \\
\hline 2 & Useful & 85 & 34 \\
\hline \multirow[t]{2}{*}{3} & Not Useful & 35 & 14 \\
\hline & Total & 250 & 100 \\
\hline
\end{tabular}

Table- 5 shows that $52 \%$ of the total 250 respondents mentioned that the Kudumbshree units are 'very useful', $4 \%$ considered the units 'useful' followed by $14 \%$ believed that Kudumbshree units have no usefulness in their lives.

Usefuiness of Kudumbashree in respondent's life

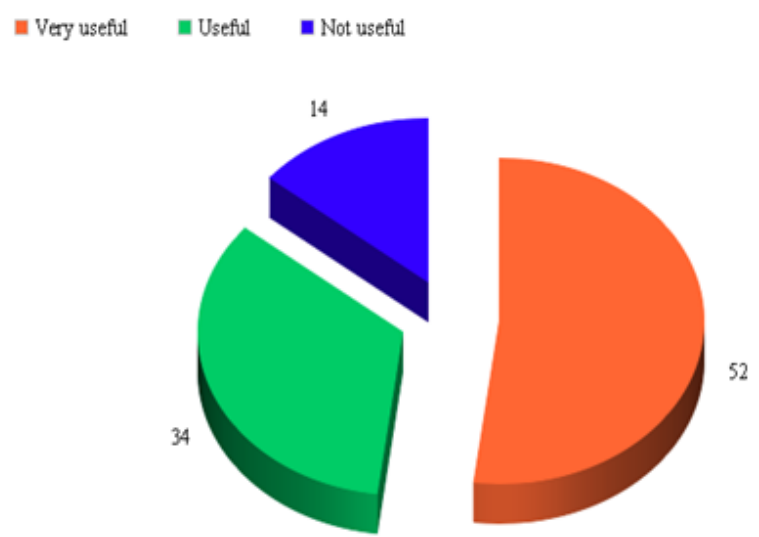

Table 6: Increasing of income per year

\begin{tabular}{|c|c|c|c|}
\hline SI.No. & $\begin{array}{l}\text { Income Range } \\
\text { (Rs.) }\end{array}$ & $\begin{array}{l}\text { Number } \\
\text { respondents }\end{array}$ & Percentage \\
\hline 1 & Less than 5000 & 9 & 4 \\
\hline 2 & $5001-10000$ & 14 & 5.6 \\
\hline 3 & $10001-20000$ & 16 & 6.4 \\
\hline 4 & 20001-30000 & 73 & 29.2 \\
\hline 5 & $300001-40000$ & 87 & 34.8 \\
\hline \multirow[t]{2}{*}{6} & Above 40000 & 50 & 20 \\
\hline & Total & 250 & 100 \\
\hline
\end{tabular}

Table- 6 shows that for $34.8 \%$ of the total 250 respondents income increased to Rs. 30001-40000 per year and for 29.2\% of respondents, income per year increased to Rs.20001-30000. Lastly, for $20 \%$ of the respondents the rise in income was to Rs.40000/- . 
Kudumbshree members are engaged in various occupations for earning their livelihood. Information about the occupation of the Kudumbashree members under study was collected. They were reported as in Table-7 below:

Table 7: Occupation-wise Distribution of Kudumbshree Members

\begin{tabular}{|l|l|ll|} 
SI.No & Occupation & $\begin{array}{l}\text { Number } \\
\text { respondents }\end{array}$ & of percentage \\
\hline 1 & Agriculture & 12 & 4.8 \\
2 & Dairy & 8 & 3.2 \\
\hline 3 & Business & 58 & 23.2 \\
\hline 4 & House Wife & 73 & 29.2 \\
\hline 5 & Skilled Laborer & 40 & 16 \\
\hline 6 & Unskilled Laborer & 54 & 21.6 \\
\hline 7 & Others & 5 & 2 \\
\hline & Total & $\mathbf{2 5 0}$ & $\mathbf{1 0 0}$ \\
\hline
\end{tabular}

The largest share of Kudumbshree members was found to be housewives (29.2\%), followed by entrepreneurs in business $(23.2 \%)$ forming the next largest share. Unskilled laborers formed the next most dominant group (21.6\%) while skilled laborers $(16 \%)$ came in fourth place respectively.

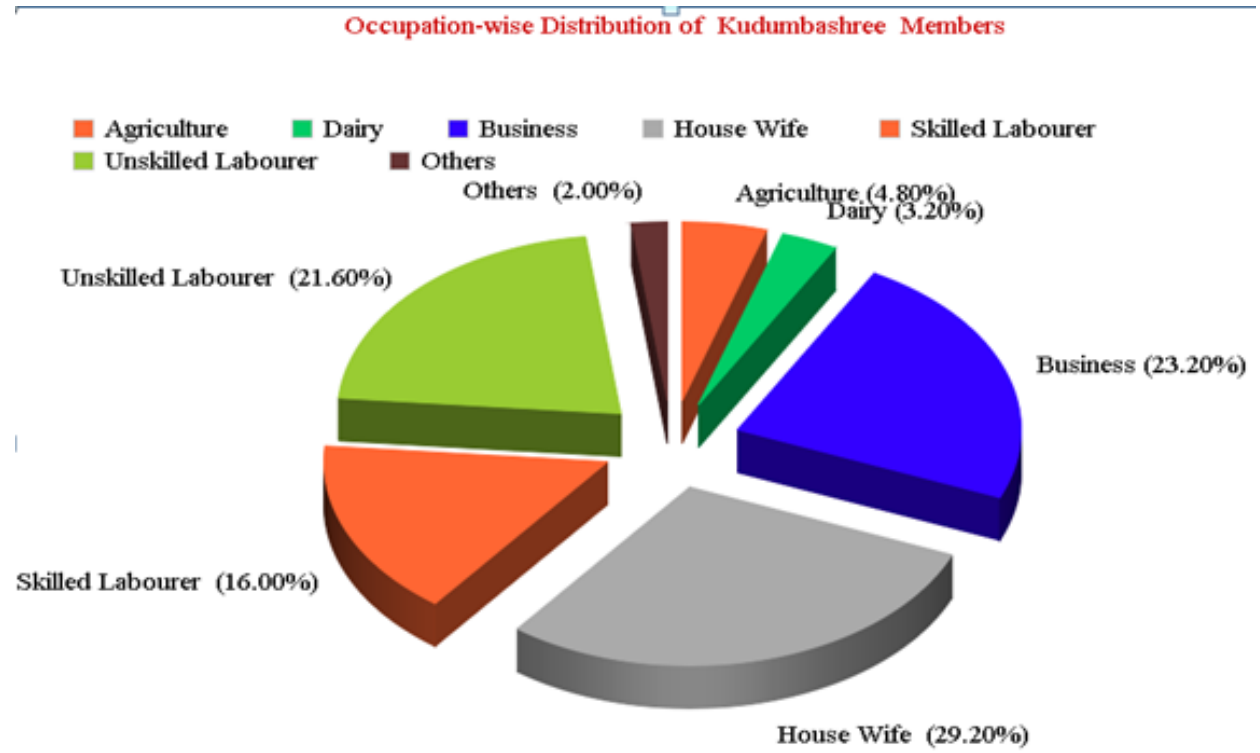

\section{FINDINGS AND CONCLUSION}

- The highest number of respondents ie. 31.6percentage fell in the 30-35 age slab, 28.4percentage in 24-29 age slab and 13.6 percentage of the total 250 respondents fell between the ages $36-41$. 
- The education level of women tabulated in Table -2 shows that 35.6 percentages are SSLC certified, 31.2 have plus two/pre-degree, 12.4 have a diploma education, 11.6 have graduation while 3.59 percentage of the total 250 respondents are post graduates.

- 52 percentage of the total 250 respondents mentioned that the Kudumbshree units are 'very useful', 29.2 percentage considered it 'useful' and 12.8 percentage observed Kudumbshree units to be 'average'. A few (4.8 percentage) said that the units need improvement while 1.2 percent believed that Kudumbshree units find no usefulness in their life.

- 34.8 percentage of the total 250 respondents income increased to Rs. 30001-40000 per year and for 29.2 percentage income per year increased to Rs.20001-30000. A fairly big group (20 percentage) had income rise to Rs.40000/- .

Kudumbashree make drastic changes in the socio-economic life of women in Kerala generally and particular in urban areas of Thiruvananthapuram. Kudumbshree project boosted the women empowering strategies adopted in Kerala state. Success of Kudumbashree is not only for individual benefits of woman but also their family, community etc. Kudumbshree has enhanced entrepreneurship and leadership, and the capacity of women to work and earn together. The status of women family has thus substantially improved. The International Conference on Population and Development in Cairo (1994) clearly pointed that the policy makers of state should understand the contribution of women in the development process. Empowering women and improving their social and economic status are essential ingredients for realizing the full potential of economic and political development of the entire society and it ensuring sustainable development.

\section{SUGGESTIONS}

Major suggestions from respondents and researchers are listed below:

- Continuous and rigorous leadership training required for individual and group members

- Long duration funding with low interest rate is required for sustainable women empowerment via entrepreneurial activities.

- Support from family is the most important factor.

- Women empowerment and awareness program should be conducted at regular intervals.

- 24 X 7 Helpline numbers are required for proper guidance.

- Audio visual aids and programs like radio, television etc. will boost the women empowerment and development strategies.

- Entrepreneurship as a subject should be taught as part of the school and graduate curriculum.

\section{REFERENCE}

[1] Local Self Government Department, Govt. of Kerala, India. (n.d.) Retrieved February 22, 2014, from http://lsgkerala.gov.in/ [2] Kudumbashree. (n.d.). Retrieved February 5, 2015, from http://www.kudumbashree.org/ [3] Gandhi,M K.(1930, October 4). To the Women of India . Young India [4]Guidelines on Women's Empowerment. (n.d.). UN News Center. Retrieved February5, 2014, from http://www.un.org/popin/unfpa/taskforce/guide/ iatfwemp.gdl.html 
[5] Manjusha K.A (2010) Tribal women empowerment through kudumbasree units: a study on the Ulladan tribe of North Paravur Taluk in Ernakulam District of Kerala, International Journal of Multidisciplinary Research 2 (12),335-350

[6] Kenneth, Kalyani and Seena, P.C (2012) Socio-economic Changes of Women through Kudumbasree:A Study from Puthenvelikkara of Kerala State, India International Research Journal of Social Sciences. 1(2), 1-7,

[7] Beevi, Subaida V and Devi, Girija (2011) Role of Self Help Groups in Empowering Rural Women in India International Journal of Interdisciplinary Social Sciences, 5(9) ,405-420

[8] Minimol, M. C and Makesh, K. G(2012) Empowering rural women in Kerala: A study on the role of Self Help Groups (SHGs), International Journal of Sociology and Anthropology 4(9), 270-280

[9] Jaya S Anand (2004) Addressing Poverty through Self Help Groups-A Case Study of Kerala. Paper presented at Network of Asia-Pacific Schools and Institutes of Public Administration and Governance (NAPSIPAG) Kuala Lumpur, Malaysia 6-8 December 2004, 1-11

[10] Shylendra, H.S.(1998), Promoting Women's Self-Help Groups: Lessons from an Action Research Project, Working Paper No. 121, Institute of Rural Management, Anand.

[11] Kavitha, V., Jiji, R. S. \& Rajkamal, P. J. (2011) Perception of effectiveness of group functioning by the members of women self-help groups in goat farming, Veterinary World, 4 (11), 507-510

[12] ICPD(1994)Gender equality, equity and empowerment of women report of International Conference on Population and Development, Cairo (5-13 September). 